\title{
Extraction and Profiling of Lipids of Isolated Strain Chlorella fw-12 by GC-MS
}

\author{
Parveen Kumar ${ }^{1}$, Devendra Kumar ${ }^{2}$, Priyanka Nehra ${ }^{2}$ and P.K. Sharma ${ }^{3}$ \\ ${ }^{1}$ Department of Microbiology, C. C. S. University, Meerut, India \\ ${ }^{2}$ Department of Microbiology, Kurukshetra University Kurukshetra, Haryana, India \\ ${ }^{3}$ Department of Genetics and Plant Breeding, C. C. S. University, Meerut, India \\ *Corresponding author
}

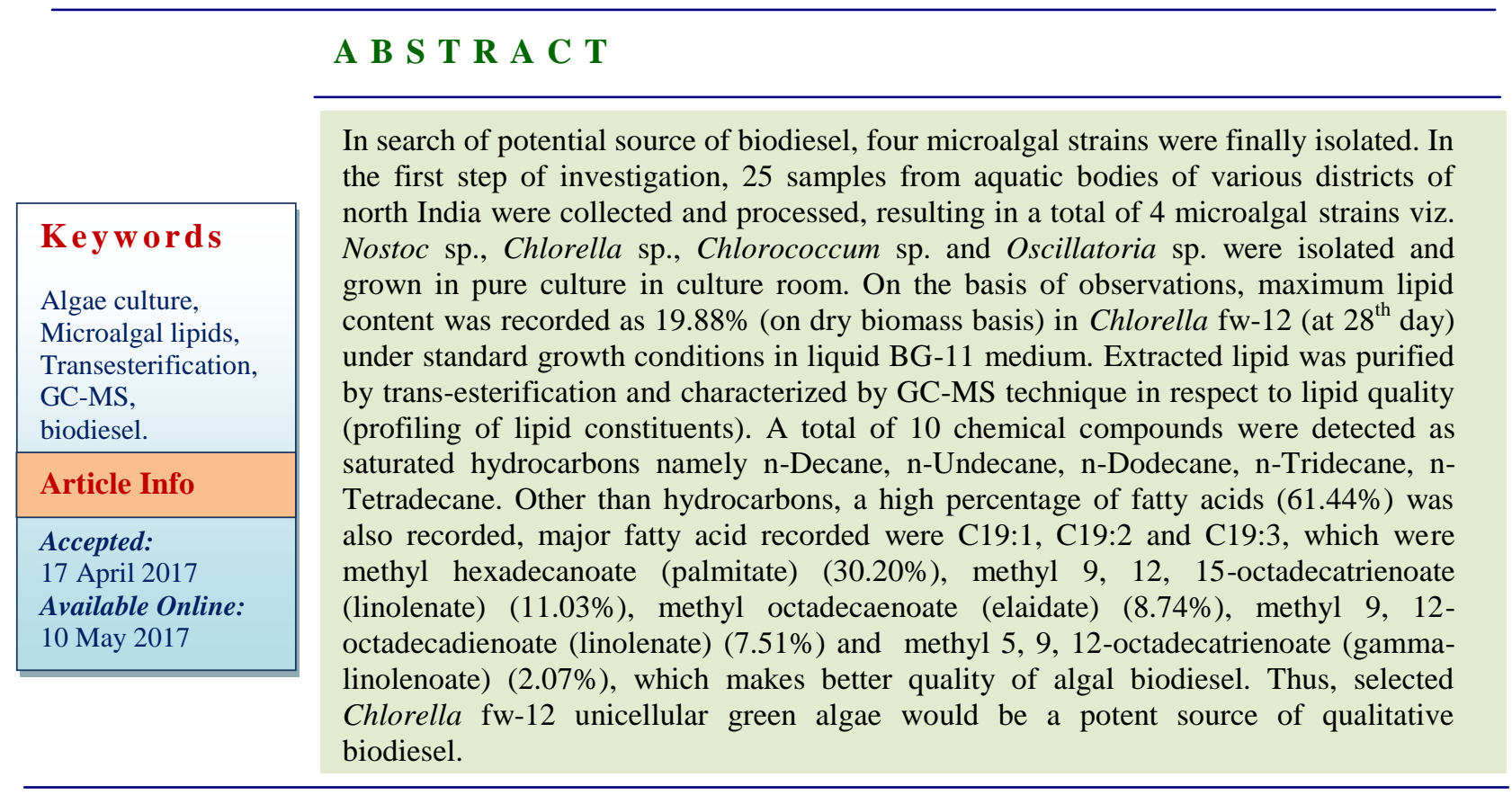

\section{Introduction}

The sustainability of algal biofuel production systems is achievable. There is regular research on biodiesel fuel into finding more and more appropriate source to enhance oil yield in algal cells. Fossil fuel energy resources are diminishing rapidly and most importantly the liquid fossil fuel will be diminished by the year about 2050 . Additionally, fossil fuels are directly related to air pollution, land and water degradation. In order to replace all fossil fuel usage entirely, a large amount of biomass is required to manufacture sufficient bio-oil. Research on biofuel presently focuses on high amount of oil yield. In these circumstances, biofuel from renewable sources like microalgae can be a substitute to reduce our dependency on fossil fuels and assist to maintain the healthy global environment and economic sustainability (Chisti, 2007). Over 50,000 microalgal species are present globally in aquatic and terrestrial environment, 
implying their widespread availability. Different microalgal species may vary in their lipid content from about $5 \%$ to $75 \%$ by weight of dry biomass (Um and Kim, 2009; Sydney et al., 2010). Microalgae has ability to utilize non-arable land and waste water resources with few competing uses, which makes algal biofuel production systems superior to biofuels based on terrestrial biomass. It has developed great interest in government sector, non-government organization, and private sector and among researchers. Recent initiatives clearly indicate this interest at all levels of government and in private sector in the development of algal biofuels technologies and enterprises. Production of biofuel from feed stocks generally consumed by humans or animals can produce a problem, which can be the root cause of worldwide dissatisfaction.

Fatty acids are the major component of lipids, and the physical, chemical, and physiological properties of a lipid class depend primarily on its fatty acid composition. Lipids and fatty acids are the primary metabolites of microalgae to produce biodiesel. Chlorella vulgaris (Gouveia et al., 2009), Scenedesmus obliquus (Da-Silva et al., 2009; Gouveia et al., 2009; Sahu et al., 2013), have been extensively studied. In order to define a lipid class, it is must to define its fatty acids also. Fatty acids are compounds which are synthesized naturally through condensation of malonyl coenzyme A units by a fatty acid synthase complex. They usually contain even numbers of carbon atoms in straight chains (generally $\mathrm{C}_{14}$ to $\mathrm{C}_{24}$ ), either saturated or unsaturated. Synthesis of neutral lipids in the form of (triacylglycerides) TAG can be induced in many species under stress conditions. These lipids are suitable initiators for biodiesel production (Miao and $\mathrm{Wu}, 2006$; Hu et al., 2008). Trans-esterification of these algal lipids convert crude lipids into biodiesel on reaction with alcohol (generally methanol) and sodium hydroxide act as catalyst and glycerol is produced as byproduct.

\section{Materials and Methods}

\section{Sampling and isolation of microalgae}

Samples were collected in five stages as these all stages include the probability of finding different species of microalgae due to season change (summer to rainy and rainy to winter) favours the change in environmental conditions (Tables 1 and 2). All the water samples were collected in blue capped sample containers (around $100 \mathrm{ml}$ water). All the samples were stored at $4^{0} \mathrm{C}$ in refrigerator.

\section{Enrichment of samples}

Enrichment culture techniques were used to obtain unialgal colonies of microalgae using Bold Basal medium (Bold, 1949; Bischoff and Bold, 1963) in culture room at 3.5 klux light intensity with $16: 8$ light and dark period and $28 \pm 22^{\circ} \mathrm{C}$ temperature. The $\mathrm{pH}$ of the medium was maintained at 8.0for optimal growth of cultures (Table 3 ).

Sterilized Bold Basal medium (BBM) was poured in $250 \mathrm{ml}$ conical flasks and autoclaved. Each $1 \mathrm{ml}$ of collected water samples were inoculated in each flask and kept in culture room for a period of 10-15 days, which is maintained with optimal light intensity and temperature.

After incubation period green coloured growth of algal cells was observed and this was picked with the help of Pasteur pipettes in order to obtain unialgal cells. Unialgal cell was re-cultured in another $250 \mathrm{ml}$ conical flask containing $100 \mathrm{ml}$ sterilized Bold Basal medium, incubated again for 10-15 days.

Solid agar based medium was prepared by dissolving 15-18 $\mathrm{g}$ of purified agar in 1 liter 
of medium and autoclaved before use for maintenance of the cultures. Plates were incubated in culture room for a period of 1015 days. The isolated colonies were picked up repeatedly and microalgae strains were purified by repeated sub culturing, plating and streaking on the appropriate medium. Isolated microalgae strains from selected habitat were grown and maintained in Bold Basal medium (BBM) under similar conditions. Cultures were regularly streaked on plate having appropriate solid medium to maintain purity of cultures which was examined several times by microscopic observation at regular intervals. Discrete colonies were inoculated in fresh medium and used for the study at exponential phase.

\section{Micromanipulation}

Isolation of microalgal cells from different type of aquatic samples was carried out by using solid agar based medium as well as broth Bold Basal medium. Greenish colonies of cells was several times recultured on freshly prepared agar plates and also subcultured in liquid medium. After incubation for 15-20 days, 2-3 types of growth of cells were visible. Microalgal colonies obtained from Petri dishes incubated according to above mentioned methods were transferred carefully to the conical flasks of $250 \mathrm{ml}$ containing $100 \mathrm{ml}$ liquid BBM with the help of inoculation loop. All the flasks were placed onto rack maintained with light intensity and temperature. After incubation for 15-20 days, color of transparent medium turns green. Some of the flasks show web like growth of microalgal cells of different genera. Out of these multi algal colonies, Pasture pipptes were used to find out unialgal growth. In this method, three drops of sterilized BBM was kept on a glass slide. A little quantity of algal cells was sucked with the help of sucker and poured into first drop of sterilized medium. Again suck it gently and transfer into second and third drop in order to find unialgal cells. Finally transfer it gently to a conical flask containing $100 \mathrm{ml}$ sterilized BBM. After the incubation period of 15-20 days unialgal cell growth appeared. Unialgal cells were then transferred to BG-11 medium.

\section{Serial dilution method}

Enrichment sample containing a large number of microalgal cells were isolated by serial dilution method. A dilution from $10^{-1}-10^{-10}$ was made in sterilized test tubes containing 9 $\mathrm{ml}$ BBM. One $\mathrm{ml}$ of enrichment sample was transferred into each test tubes labeled with dilution factor from $10^{-1}-10^{-10}$ respectively. Dilution factor $10^{-6}-10^{-10}$ was used for spreading onto the freshly prepared agar plates. Petri dishes were placed onto rack maintained with light intensity and temperature. After incubation period of 15-20 days a number of colonies of green color was observed.

For the purpose of axenic strains of microalgal cultures, the method involving triple antibiotic solution was employed (Kaushik, 1987).

\section{Growth and maintenance}

Microalgal strains of different isolates were grown and maintained in chemically defined modified BG-11 medium (Stainer et al., $1971)$ at $30 \pm 2{ }^{\circ} \mathrm{C}$ under a light intensity of 3.5 klux and light: dark cycle of (16: 8) hours. $\mathrm{pH}$ of the medium was maintained in the range of 8.0 - 8.2 for optimal growth of all isolates. Solid agar medium was prepared by using 15-18 $\mathrm{g}$ of purified agar per litre of BG11 medium (1.5-1.8\%) and autoclaved well before use for maintenance of the isolated cultures. After an incubation period of 14 days, all isolated cultures were subjected to streaking on agar plates of BG-11 medium for maintenance of pure colonies under standard cultural conditions. These colonies were picked up and inoculated in $250 \mathrm{~mL}$ flasks 
containing $100 \mathrm{~mL}$ BG-11 medium and incubated till exponential phase of 14 days. Biomass was harvested on $14^{\text {th }}$ day, $21^{\text {st }}$ day and $28^{\text {th }}$ day and processed for extraction of lipids. Extraction of lipids was carried out by Bligh and Dyer (1959) method.

\section{Analysis}

All isolated microalgalstrains were identified accordingly to keys given by Desikachary (1959) and Geitler (1932), for members of cyanophyceae and keys given by Komarek et al., (1983), Hindak (1988) and Prescott (1961), for the members of chlorophyceae. Morphological studies were carried out on the specimens of exponential growth phase. All the measurements on fresh material were performed on each morphological variable by using a light microscope (Olympus, model: CX40RF200). Micrographs were taken by Olympus (CAMEDIA C-5060 WIDE ZOOM) digital compact camera. Isolates were identified at genus level on the basis of color of thallus, trichomes and heterocyst etc. All the isolates were grown in 3 replicates for analysis of biomass and lipid and mean of the three replicates was obtained to have mean estimates of biomass weight gravimetrically (g/l) and lipid \%.

The lipid profile was done by using gas chromatography (model Agilent technologies 7890A GC system equipped with an Agilent 5975C inert XL EI/CI MSD triple axis detector). The compounds were profiled on a $30 \mathrm{mX} 250 \mu \mathrm{mX} 0.5 \mu \mathrm{m}$ HP-5MS column. Carrier gas was Helium at the rate of $0.7 \mathrm{~mL}$ per minute. The temperature conditions were $40{ }^{0} \mathrm{C}$ for one minute with a hold for a minute followed by $250{ }^{0} \mathrm{C}$ for ten minutes at the rate of $15{ }^{0} \mathrm{C}$ per minute and hold for ten minutes. The instrument contained split/splitters injector (445137A) with auto injection facility. Mass detector (Mass EI) temperature was $260{ }^{\circ} \mathrm{C}$.

\section{Results and Discussion}

In this work four algal species (2 green algae and 2 cyanobacteria) were finally isolated and purely grown in culture room. Isolate number 11, 02, 06 and 09 were finalized, grown in pure culture and carried for biomass and lipid extraction process. Out of these four isolates Chlorella fw-12 was produced maximum biomass (Fig. 1) and lipid \% (0.93 $\pm 0.07 \mathrm{~g} / 1$ and $19.88 \pm 0.07 \%$ on $28^{\text {th }}$ day). Extracted lipid was purified and profiled by GC-MS.

\section{Lipids purification and characterization}

Isolate Chlorellafw-12was selected as potent microalgae for biodiesel purpose, crude lipid extracted from this isolate was purified via trans-esterification, and fatty acid methyl esters (FAME) were produced. Purified lipid samples were processed and subjected to lipid characterization by GCMS technique. The results are presented in table 4 and figures 4 and 5 .

Microalgae Chlorella fw-12 was investigated for lipid profiling of chemical constituents. A number of chemical compounds comprising hydrocarbons, saturated and unsaturated fatty acids were detected. GC-MS profiling of this strain shows a total of 10 chemical compounds which comprised saturated hydrocarbons namely n-Decane, n-Undecane, nDodecane, n-Tridecane, n-Tetradecane. Other than hydrocarbons, a high percentage of fatty acids (61.44\%) was also recorded, major fatty acid recorded were C19:1, C19:2 and C19:3, which were methyl hexadecanoate (palmitate) $(30.20 \%)$, methyl $9, \quad 12, \quad 15$-octadecatrienoate (linolenate) $(11.03 \%)$, methyl octadecaenoate (elaidate) (8.74\%), methyl 9, 12-octadecadienoate (linolenate) (7.51\%) and methyl 5, 9, 12octadecatrienoate (gamma-linolenoate) (2.07\%) (Tables 5 and 6). 
Int.J.Curr.Microbiol.App.Sci (2017) 6(5): 1801-1810

Table.1 District wise samples detail

\begin{tabular}{|l|l|l|l|l|l|}
\hline Shamli & Baghpat & Garhmukhteshwar & Meerut & $\begin{array}{l}\text { Nanital/ } \\
\text { Ranikhat }\end{array}$ & Total \\
\hline 02 & 06 & 04 & 20 & 08 & 40 \\
\hline
\end{tabular}

Table.2 Samples type (type of sampling site)

\begin{tabular}{|l|l|c|}
\hline S.No. & Type of sample & No. of samples \\
\hline 1. & Fresh water samples & 08 \\
\hline 2. & Sewage water samples & 20 \\
\hline 3. & Pond water samples & 05 \\
\hline 4. & Lake water samples & 04 \\
\hline 5. & Cropland soil samples & 01 \\
\hline 5. & Shallow water samples & 02 \\
\hline
\end{tabular}

Total no. of samples $=\mathbf{4 0}$

Table.3 Details of mono-algal colonies obtained in liquid/solid BBM medium

\begin{tabular}{|c|c|l|c|}
\hline S. No. & Isolate No. & \multicolumn{1}{|c|}{ strain } & division \\
\hline 1. & 11. & Nostoc sp. & Cyanobacteria \\
\hline 2. & 02. & Chlorella sp. & Green algae \\
\hline 3. & 06. & Chlorococcum $\mathrm{sp}$. & Green algae \\
\hline 4. & 09. & Ossilatoria $\mathrm{sp}$. & Cyanobacteria \\
\hline
\end{tabular}

Table.4 Estimates of dry biomass (g/l) of isolated microalgae

\begin{tabular}{|c|c|c|c|c|c|c|c|c|c|}
\hline & \multicolumn{9}{|c|}{ Dry biomass (g/l) } \\
\hline \multirow{2}{*}{$\begin{array}{l}\text { Isolate } \\
\text { No. }\end{array}$} & \multicolumn{3}{|c|}{$14^{\text {th }}$ day } & \multicolumn{3}{|l|}{$21^{\text {st }}$ day } & \multicolumn{3}{|c|}{$28^{\text {th }}$ day } \\
\hline & $\begin{array}{l}\text { Mean } \\
(\mathrm{g} / \mathrm{l}) \pm \mathrm{SE}\end{array}$ & S.D. & $\begin{array}{l}\text { C.V. } \\
\%\end{array}$ & $\begin{array}{l}\text { Mean } \\
(\mathrm{g} / \mathrm{l}) \pm \mathrm{SE}\end{array}$ & S.D. & $\begin{array}{l}\text { C.V. } \\
\%\end{array}$ & $\begin{array}{l}\text { Mean } \\
(\mathrm{g} / \mathrm{l}) \pm \mathrm{SE}\end{array}$ & S.D. & $\begin{array}{l}\text { C.V. } \\
\%\end{array}$ \\
\hline 11 & $0.53 \pm 0.09$ & 0.15 & 0.29 & $0.67 \pm 0.03$ & 0.06 & 0.09 & $1.23 \pm 0.09$ & 0.15 & 0.12 \\
\hline 02 & $0.73 \pm 0.07$ & 0.12 & 0.16 & $0.93 \pm 0.03$ & 0.06 & 0.06 & $0.93 \pm 0.07$ & 0.12 & 0.12 \\
\hline 06 & $0.67 \pm 0.03$ & 0.06 & 0.09 & $0.97 \pm 0.03$ & 0.06 & 0.06 & $1.27 \pm 0.03$ & 0.06 & 0.05 \\
\hline 09 & $0.37 \pm 0.03$ & 0.06 & 0.16 & $0.83 \pm 0.03$ & 0.06 & 0.07 & $1.13 \pm 0.03$ & 0.06 & 0.05 \\
\hline
\end{tabular}

Table.5 Lipid \% of isolated microalgae

\begin{tabular}{|l|c|l|l|l|l|l|l|l|l|}
\hline \multirow{2}{*}{$\begin{array}{l}\text { Isolate } \\
\text { No. }\end{array}$} & \multicolumn{3}{|c|}{$\mathbf{1 4}^{\text {th }}$ day } & \multicolumn{3}{c|}{$\mathbf{2 1}^{\text {st }}$ day } & \multicolumn{3}{c|}{$\mathbf{2 8}^{\text {th }}$ day } \\
\cline { 2 - 10 } & $\begin{array}{l}\text { Lipid \% } \\
\text { SE(M) } \pm\end{array}$ & S.D. & $\begin{array}{l}\text { C.V. } \\
\%\end{array}$ & $\begin{array}{l}\text { Lipid \% } \\
\text { SE(M) } \pm\end{array}$ & S.D. & $\begin{array}{l}\text { C.V. } \\
\%\end{array}$ & $\begin{array}{l}\text { Lipid \% } \\
\text { SE(M) } \pm\end{array}$ & S.D. & $\begin{array}{l}\text { C.V. } \\
\%\end{array}$ \\
\hline 11 & $2.18 \pm 0.11$ & 0.19 & 0.09 & $4.05 \pm 0.02$ & 0.03 & 0.01 & $5.44 \pm 0.11$ & 0.20 & 0.04 \\
\hline 02 & $11.17 \pm 0.69$ & 1.19 & 0.11 & $14.27 \pm 0.33$ & 0.57 & 0.04 & $19.88 \pm 0.07$ & 0.13 & 0.01 \\
\hline 06 & $8.23 \pm 0.22$ & 0.38 & 0.05 & $10.77 \pm 0.34$ & 0.59 & 0.05 & $13.40 \pm 0.31$ & 0.53 & 0.04 \\
\hline 09 & $4.13 \pm 0.04$ & 0.06 & 0.02 & $5.93 \pm 0.09$ & 0.15 & 0.03 & $8.52 \pm 0.20$ & 0.35 & 0.04 \\
\hline
\end{tabular}


Fig.1 Biomass ( $g / l)$ of isolated microalgae

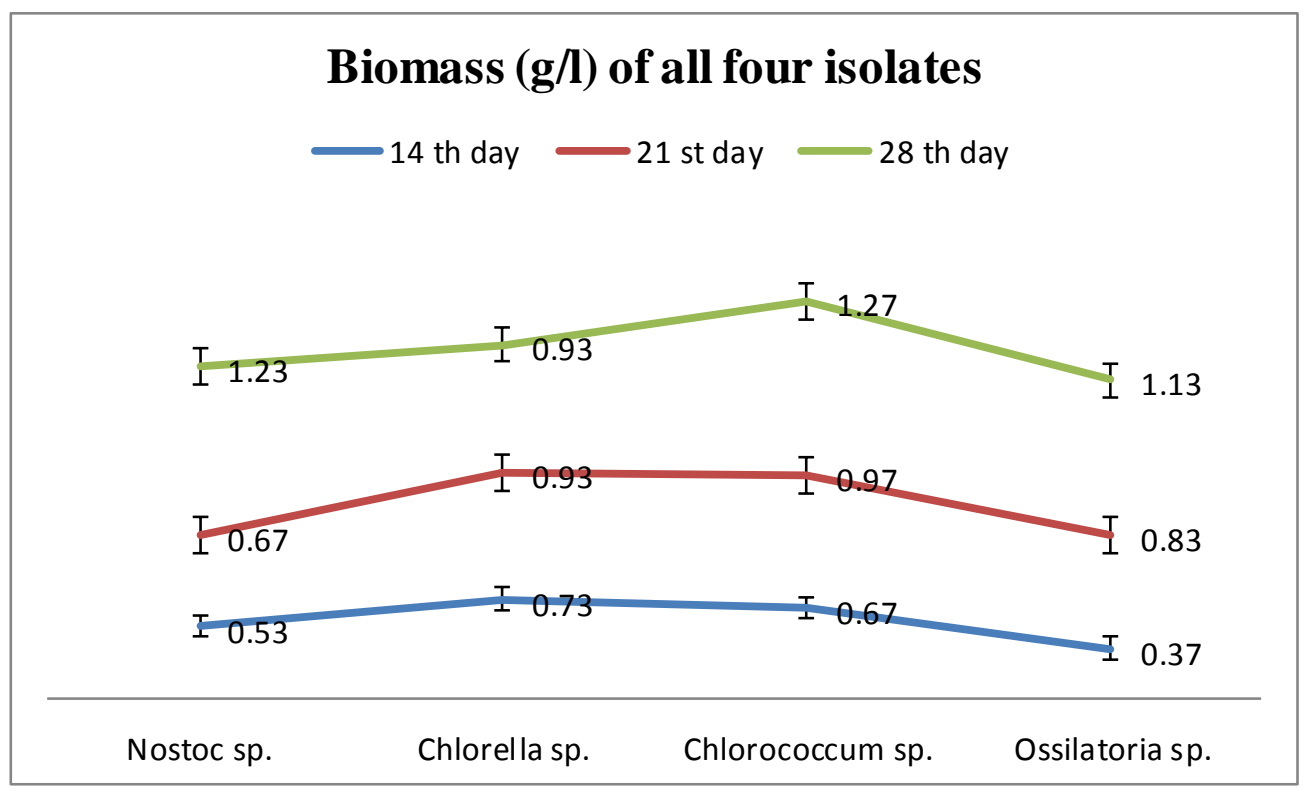

Table.6 Lipid profile of green microalgal strain Chlorella fw-12.

\begin{tabular}{|l|l|l|l|l|l|l|}
\hline S. No. & $\begin{array}{l}\text { Retention } \\
\text { time (in } \\
\text { minute) }\end{array}$ & Chemical name & $\begin{array}{l}\text { Chemical } \\
\text { formula }\end{array}$ & $\begin{array}{l}\text { Shorthand } \\
\text { designation }\end{array}$ & $\begin{array}{l}\text { Molecular } \\
\text { wt. (g/mol) }\end{array}$ & $\begin{array}{l}\text { Area (in } \\
\text { percentage) }\end{array}$ \\
\hline 1. & 3.471 & n- Decane & $\mathrm{C}_{10} \mathrm{H}_{22}$ & $\mathrm{C} 10: 0$ & $\begin{array}{l}142.28 \\
\mathrm{~g} / \mathrm{mol}\end{array}$ & 3.71 \\
\hline 2. & 4.794 & n- Undecane & $\mathrm{C}_{11} \mathrm{H}_{24}$ & $\mathrm{C} 11: 0$ & $\begin{array}{l}156.30 \\
\mathrm{~g} / \mathrm{mol}\end{array}$ & 6.16 \\
\hline 3. & 6.212 & n- Dodecane & $\mathrm{C}_{12} \mathrm{H}_{26}$ & $\mathrm{C} 12: 0$ & $\begin{array}{l}170.33 \\
\mathrm{~g} / \mathrm{mol}\end{array}$ & 5.50 \\
\hline 4. & 7.637 & n- Tridecane & $\mathrm{C}_{13} \mathrm{H}_{28}$ & $\mathrm{C} 13: 0$ & $\begin{array}{l}184.36 \\
\mathrm{~g} / \mathrm{mol}\end{array}$ & 5.51 \\
\hline 5 & 9.010 & n- Tetradecane & $\mathrm{C}_{14} \mathrm{H}_{30}$ & $\mathrm{C} 14: 0$ & $\begin{array}{l}198.38 \\
\mathrm{~g} / \mathrm{mol}\end{array}$ & 3.40 \\
\hline 6. & 15.276 & $\begin{array}{l}\text { Methyl hexadecanoate } \\
\text { (Palmitate) }\end{array}$ & $\mathrm{C}_{17} \mathrm{H}_{34} \mathrm{O}_{2}$ & $\mathrm{C} 17: 0$ & $\begin{array}{l}270.45 \\
\mathrm{~g} / \mathrm{mol}\end{array}$ & 30.20 \\
\hline 7. & 16.832 & $\begin{array}{l}\text { Methyl 5, 9, 12- } \\
\text { Octadecatrienoate } \\
\text { (Gamma- linolenate) }\end{array}$ & $\mathrm{C}_{19} \mathrm{H}_{32} \mathrm{O}_{2}$ & $\mathrm{C} 19: 3$ & $\begin{array}{l}264.40 \\
\mathrm{~g} / \mathrm{mol}\end{array}$ & 2.07 \\
\hline 8. & 16.987 & $\begin{array}{l}\text { Methyl 9, 12- } \\
\text { Octadecadienoate } \\
\text { (Linolenate) }\end{array}$ & $\mathrm{C}_{19} \mathrm{H}_{34} \mathrm{O}_{2}$ & $\mathrm{C} 19: 2$ & $\begin{array}{l}294.47 \\
\mathrm{~g} / \mathrm{mol}\end{array}$ & 7.51 \\
\hline 9 & 17.050 & $\begin{array}{l}\text { Methyl 9, 12, 15- } \\
\text { Octadecatrienoate } \\
\text { (Linolenate) }\end{array}$ & $\begin{array}{l}\mathrm{C}_{19} \mathrm{H}_{32} \mathrm{O}_{2} \\
\text { (Elaidate) }\end{array}$ & $\mathrm{C} 19: 3$ & $\begin{array}{l}292.45 \\
\mathrm{~g} / \mathrm{mol}\end{array}$ & 11.03 \\
\hline 10 & 17.095 & $\begin{array}{l}\text { Methyl octadecaenoate } \\
\text { (Elate }\end{array}$ & $\mathrm{C}_{19} \mathrm{H}_{36} \mathrm{O}_{2}$ & $\mathrm{C} 19: 1$ & $\begin{array}{l}296.48 \\
\mathrm{~g} / \mathrm{mol}\end{array}$ & 8.74 \\
\hline
\end{tabular}


Fig.2 Micrographs of isolated microalgae: (a) Nostoc sp.; (b) Chlorella sp.; (c) Chlorococcum sp.; (d) Ossilatoria sp.

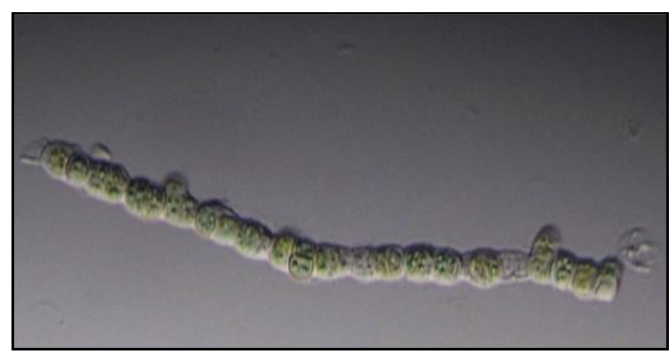

Nostoc sp.

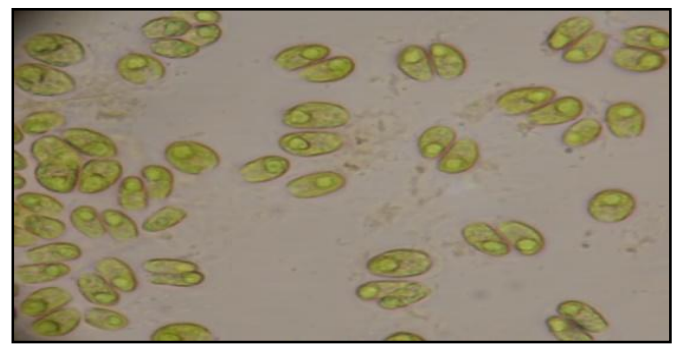

Chlorococcum sp.

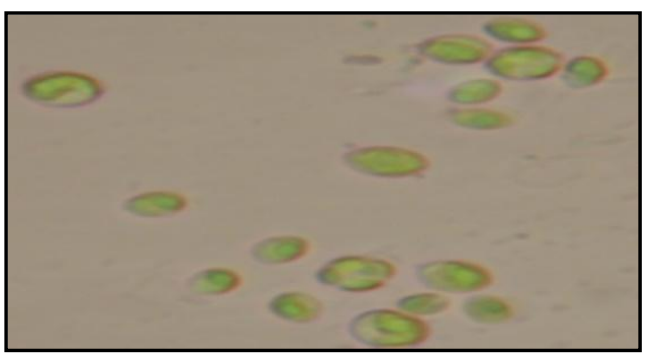

Chlorella sp.

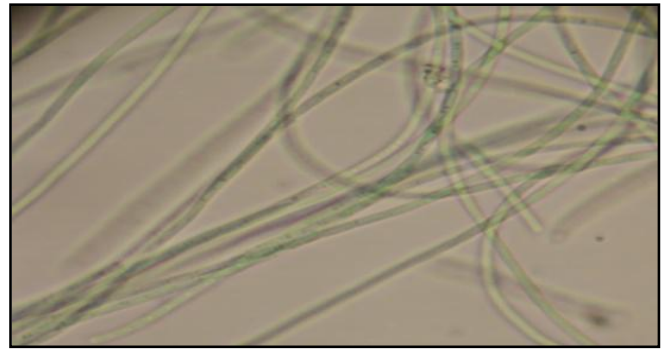

Ossilatoria $s p$.

Fig.3 Lipid (\%) of isolated microalgae

\section{Lipid \% of all four isolates}

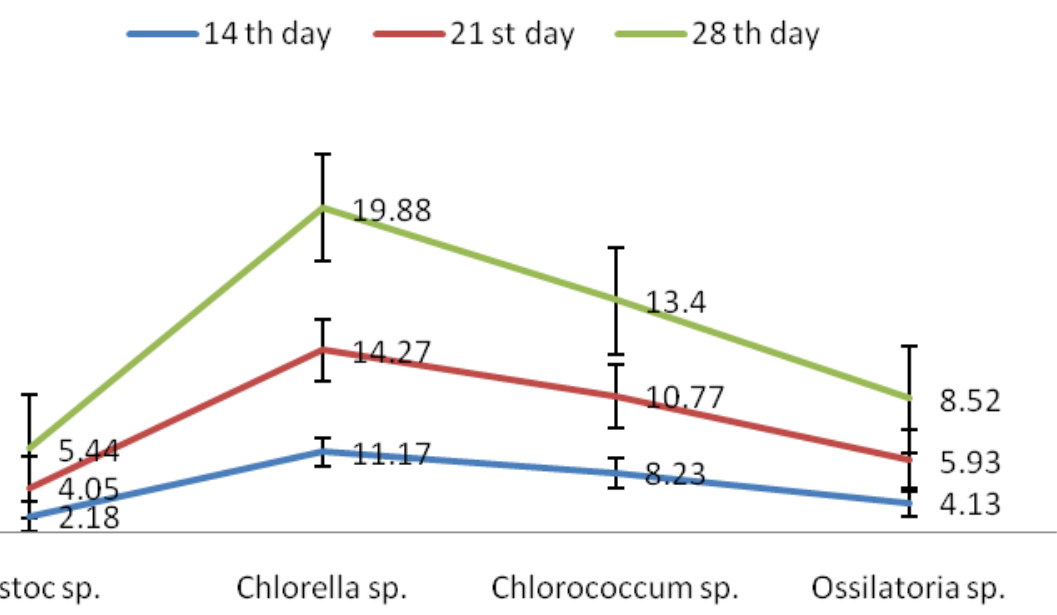


Fig.4 Percentage of different fatty acids in lipids

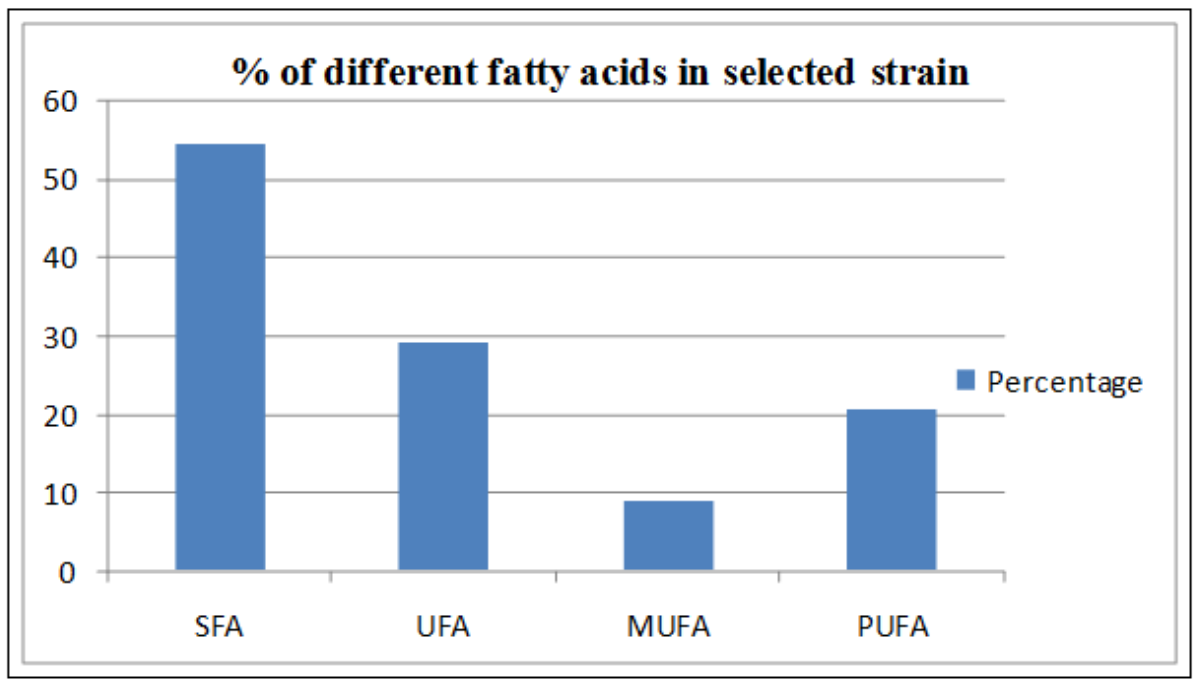

Abbreviations: SFA- Saturated fatty acids; USFA-Unsaturated fatty acids; MUFA- Monounsaturated fatty acids; PUFA-Polyunsaturated fatty acids

Fig.5 Chromatogram of lipids profile of selected second best green micro algal strain Chlorella fw-12

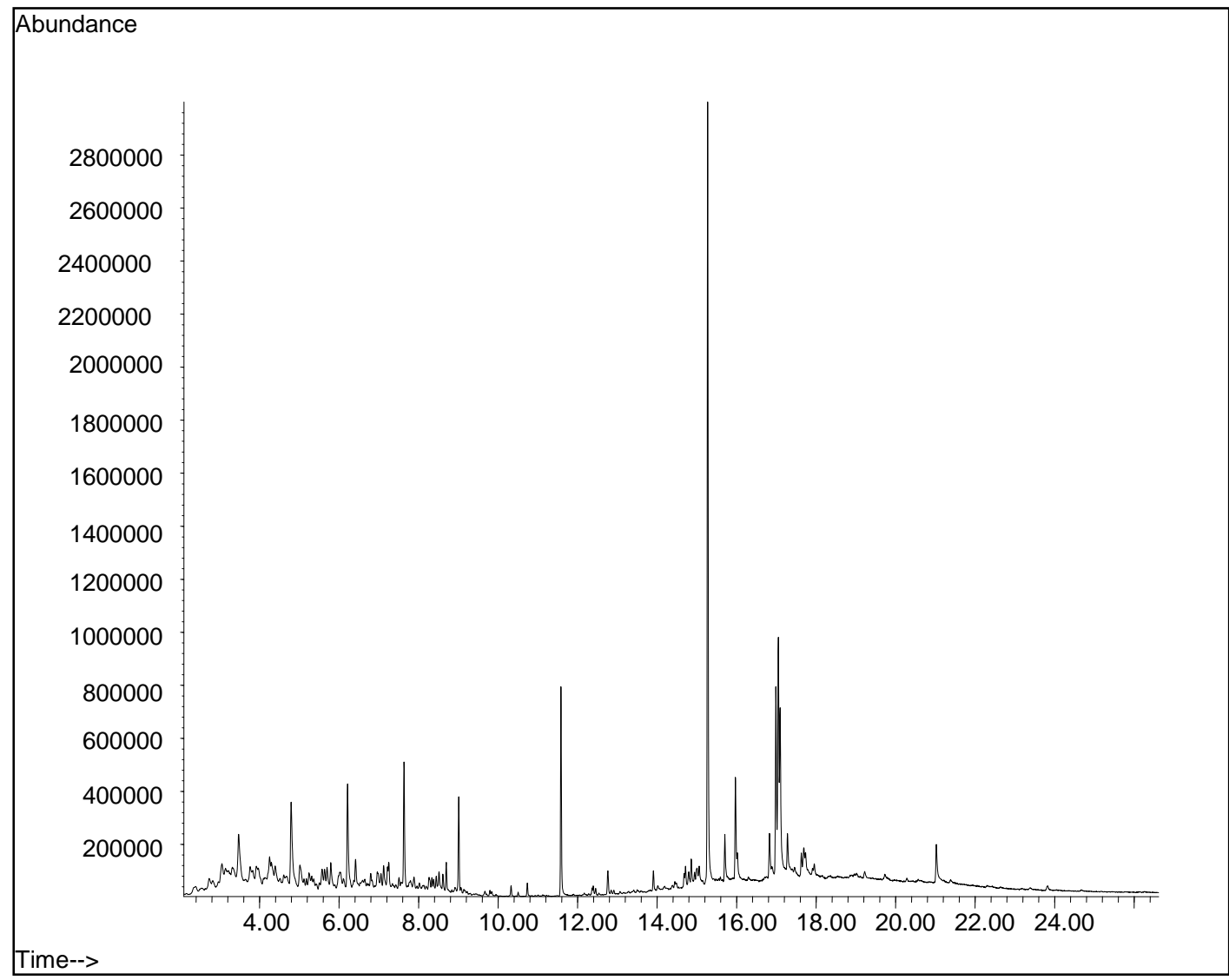


In support of our isolated potent microalgal isolate Chlorella fw-12, a recent study has shown that other green algae Scenedesmus dimorphus performed better than other isolates with respect to important growth parameters and lipid content of near about $30 \%$ of dry biomass (Gour et al., (2016). Selvarajan et al., (2015) reported $42.1 \% \pm$ $2.5 \%$ (of dry biomass) of lipid in case of Chlorella vulgaris. Yang et al., (2012) isolated four microalgal strains from fresh water bodies and lipid was extracted. Lipid percentage on dry biomass basis was observed to be $28 \%$ in Chlorella sp., $51 \%$ in Chlamydomona sreinhardtii, $39 \%$ in Monoraphidium dybowskii and $43 \%$ in Chlorella sp.

In conclusion, in this study we discussed on ability of microalgae to use as biofuel in order to replace fossil fuels. Microalgae have its environmental benefits and the fact that, it is a renewable source of energy and can remove greenhouse gases (GHG) also from environment. Now it can be an achievable goal. Selection of oleaginous species out of large number of microalgal species was done. Chlorella species are high lipid accumulating green algae among all four isolates. Large amount of fatty acids found in lipid profile of our selected isolate Chlorella fw-12, which makes this, as more potential feedstock for biofuel purpose. Major fatty acid recorded were C19:1, C19:2 and C19:3, which were methyl hexadecanoate (palmitate) $(30.20 \%)$, methyl $9, \quad 12, \quad 15$-octadecatrienoate (linolenate) (11.03\%), methyl octadecaenoate (elaidate) $(8.74 \%)$, methyl 9, 12-octadecadienoate (linolenate) $(7.51 \%)$ and methyl 5, 9, 12octadecatrienoate (gamma-linolenoate) (2.07\%).

\section{Acknowledgement}

Authors are very thankful to the University Grants Commission (UGC) New Delhi for financial support and Head, Department of Microbiology, C. C. S. University Meerut for providing all necessary facilities to carry out this research work.

\section{References}

Bischoff, H.W. and Bold, H.C. 1963. Phycological Studies IV. Some Soil Algae From Enchanted Rock and Related Algal Species. University of Texas, Austin, 63(18): 1 - 95.

Bligh, E.G. and Dyer, W.J. 1959. A rapid method of total lipid extraction and purification. Can. J. Biochem. Phys., (37): pp. 911-991.

Chisti, Y. 2007. Biodiesel from Microalgae, Biotechnol. Adv., (25):pp. 29s4-306.

Da-Silva, T.L. Reis, A. Medeiros, R. Cristina, Al., Oliveira and Gouveia, L. 2009. Oil Production Towards Biofuel from Autotrophic Microalgae Semicontinuous Cultivations Monitorized by Flow Cytometry, Appl. Biochem. Biotechnol., (159): pp. 568578.

Desikachory, TV. 1959. Monograph on algae, Cyanophyta, vol. (2): Indian Council of Agriculture Research.

Geitler, L. 1931. CyanophyceaeKoeltz Scientific Books for Edition Karin Koeltz, Germany, pp. 288.

Gour, R.S.Chawla, A. Singh, H. andChauhan, R.S. 2016. Characterization and screening of native Scenedesmus sp. isolates suitable for biofuel feedstock. PLoS ONE, (11): 5 e0155321. Doi:10. 1371/journal.pone.0155321.

Gouveia, L. and Oliveira, A.C. 2009. Microalgae as a raw material for biofuels production, J Ind. Microbiol. Biotechnol., (36): pp. 269-274.

Hindák, F. 1988. Studies on the Chlorococcal Algae (Chlorophyceae). IV. Slovak Academy of Sciences, VEDA publishing house, Bratislava, Slovakia.

$\mathrm{Hu}$, Q.Sommerfeld, M. Jarvis, E.Ghirardi, M. 
Posewitz, M. Seibert, M. and Darzins, A. 2008.Microalgaltriacylglycerols as feed stocks for biofuel production: perspectives and advances, Plant J., (54):pp. 621-639.

Komárek, J. and Fott, B. 1983.Chlorophyceae (Grünalgen), Ordung: Chlorococcales. In: Huber-Pestalozzi G. (ed.), Das Phytoplankton des Süsswassers, Die Binnengewässer,(16): pp. 1-1044.

Miao, X. and Wu, Q. 2006. Biodiesel production from heterotrophic microalgal oil. Bioresour. Technol., (97): 841-846.

Prescott, G.W. 1961. Algae on the Western Great Lakes Area.WMC.Brown Company Publishers, Dubuque, Lowa.

Sahu, A., Pancha, I., Jain, D., Paliwal, C., Ghosh, T., Patidar, S., Bhattacharya, S., and Mishra, S. 2013. Fatty acids as biomarkers of microalgae. Phytochem., 89: 53-58.
Selvarajan, R., Felföld, T., Tauber, T., Sanniyasi, E., Sibanda, T. and Tekere, M. 2015. Screening and Evaluation of Some Green Algal Strains (Chlorophyceae) Isolated from Freshwater and Soda Lakes for Biofuel Production, Energies, (8): pp. 7502-752. Sydney, E.B. Sturm, W. de Carvalho, J.C. Thomaz-Soccol, V. Larroche, C. Pandey, A. and Soccol, C.R. 2010. Potential carbon dioxide fixation by industrially important microalgae, Biores. Technol., (101): pp. 5892-5896.

Um, B.H. and Kim, Y.S. 2009. Review: A chance for korea to advance algalbiodiesel technology. J. Ind. Eng. Chem., (15): pp. 1-7.

Yang, X. Lu, P. Hao, X. Shi, X. and Zhang, S. 2012. Characterization and identification of freshwater microalgal strains toward biofuel production. Biores., 7: 686-695.

\section{How to cite this article:}

Parveen Kumar, Devendra Kumar, Priyanka Nehra, P.K. Sharma. 2017. Extraction and Profiling of Lipids of Isolated Strain Chlorella fw-12 by GC-MS. Int.J.Curr.Microbiol.App.Sci. 6(5): 1801-1810. doi: https://doi.org/10.20546/ijcmas.2017.605.196 